\title{
HUBUNGAN JUMLAH OBJEK WISATA, HOTEL DAN BIRO PERJALANAN DENGAN JUMLAH WISATAWAN KE D.I.Y.
}

\author{
Atun Yulianto ${ }^{1}$, Citra Unik Mayasari ${ }^{2}$ \\ ${ }^{1}$ Universitas Bina Sarana Informatika, atun.aty@bsi.ac.id \\ ${ }^{2}$ Universitas Bina Sarana Informatika, citra.cyu@bsi.ac.id
}

\begin{abstract}
ABSTRAK
Banyaknya jumlah kunjungan wisatawan di Daerah Istimewa Yogyakarta menjadi peluang besar bagi pelaku industry pariwisata untuk mengembangkan bisnisnya. Namun demikian dibutuhkan konsistensi dalam pengembangan pengelolaan yang berkesinambungan untuk dapat bertahan dalam persaingan. Hal ini terkait dengan kreativitas pengelola untuk berinovasi dalam industry wisata agar usaha pariwisatanya diminati masyarakat. Tujuan penelitian ini adalah untuk mengetahui hubungan antara jumlah objek wisata, hotel dan biro perjalanan dengan jumlah kunjungan wisatawan ke tujuan wisata di D.I. Yogyakarta. Metode penelitian yang digunakan dengan pendekatan diskriptif kualitatif yang didukung analisis data kuantitatif. Hasil penelitian menunjukkan adanya hubungan yang signifikan antara jumlah hotel dan biro perjalanan dengan jumlah kunjungan wisatawan. Nilai signifikansi mendekati 0,000 pada tingkat probabilitas $5 \%$. Sementara jumlah objek wisata tidak memiliki hubungan erat dengan jumlah kunjungan, namun jenis objek wisata memiliki potensi hubungan terhadap jumlah kunjungan wisatawan.
\end{abstract}

Kata Kunci: Objek Wisata, Hotel, Biro Perjalanan, Kunjungan Wisatawan

\section{ABSTRACT}

The large number of tourist visits in the Special Region of Yogyakarta is a great opportunity for the tourism industry players to develop their business. However, consistency in the development of sustainable management is needed to survive in the competition. This is related to the creativity of managers to innovate in the tourism industry so that their tourism business is in demand by the community. The purpose of this study was to determine the relationship between the number of tourist objects, hotels and travel agencies with the number of tourist visits to tourist destinations in D.I. Yogyakarta. The research method used is a qualitative descriptive approach supported by quantitative data analysis. The results showed a significant relationship between the number of hotels and travel agencies with the number of tourist visits. The significance value is close to 0.000 at the 5\% probability level. While the number of tourist objects does not have a close relationship with the number of visits, the types of attractions have a potential relationship to the number of tourist visits.

Keywords: Tourism Object, Hotel, Travel Agency, Tourist Visit

\section{PENDAHULUAN}

Industri pariwisata di Yogyakarta sebelum adanya pandemi Covid-19 merupakan salah satu industri yang menjadi andalan untuk meningkatkan jumlah pendapatan asli daerah. Industri pariwisata tidak saja terdiri dari objek daya tarik wisata saja, namun juga pelaku wisata lainnya seperti perhotelan, restoran, biro perjalanan wisata dan industri pendukung lainnya. Sejak adanya pandemi sektor pariwisata sangat

ISSN: 2355-6587, e-ISSN: 2528-2220

http://ejournal.bsi.ac.id/ejurnal/index.php/jp 
terdampak dengan adanya pembatasan perjalanan baik internasional maupun domestik. Pemerintah Indonesia yang sedang berusaha menekan jumlah penyebaran virus covid-19 menerapkan kebijakan pembatasan sosial baik berskala besar maupun mikro sesuai kondisi suatu wilayah. Dengan pengaturan perjalanan, penutupan bebarapa objek wisata dan pembatasan lainnya mengakibatkan kunjungan wisatawan ke destinasi yang ada di Yogyakarta menurun drastis.

Seiring dengan adanya program vaksinasi, sektor pariwisata Yogyakarta juga perlahan berusaha bangkit kembali, baik dari sektor perhotelan, objek wisata, serta biro perjalanan. Masingmasing sektor berusaha untuk membangun kembali keunggulankeunggulan mereka agar dapat menarik kunjungan wisatawan kembali. Banyaknya minat kunjungan wisatawan di Yogyakarta menjadi peluang besar bagi pelaku industri pariwisata untuk mengembangkan bisnisnya. Namun demikian dibutuhkan konsistensi dan pengembangan pengelolaan yang berkesinambungan untuk dapat bertahan dalam persaingan. Hal ini terkait dengan kreativitas pengelola untuk berinovasi dalam industri wisata agar usaha pariwisatanya diminati masyarakat.

Yogyakarta merupakan salah satu destinasi wisata favorit bagi wisatawan lokal ataupun internasional, karena memiliki banyak jenis objek wisata, kaya akan budaya, banyak hidden spot atau wisata yang belum terekspos, serta penduduk yang ramah dikutip dari https://yoursay.suara.com/ . Hal tersebut dapat dijadikan sebagai alasan untuk kembali bangkit bagi para sektor pariwisata seperti hotel, pengelola objek wisata serta para biro perjalanan. Tidak dapat dipungkiri bahwa terciptanya tingkat kunjungan wisatawan yang tinggi, tidak terlepas dari berbagai sektor pariwisata dalam menjalin kerja sama. Masing-masing sektor pariwisata tidak dapat berdiri sendiri untuk mencapai sebuah pariwisata yang sukses. Sehingga harus terjalin sebuah hubungan kerjasama antara sektor perhotelan, sektor pengelola objek wisata dan biro perjalanan wisata.

Pada penelitian terdahulu oleh Sabrina dan Mudzhalifah (2018) tentang Pengaruh Jumlah Objek Wisata, Jumlah Wisatawan Dan Tingkat Hunian Hotel Terhadap Pendapatan Asli Daerah, dengan hasil penelitian menunjukkan bahwa Jumlah Objek Wisata, Jumlah Wisatawan, dan Tingkat Hunian Hotel memiliki pengaruh secara simultan yang signifikan terhadap PAD. Secara tidak langsung jumlah objek wisata, hotel dan biro perjalanan berpengaruh atau memiliki hubungan terhadap tingkat kunjungan wisatawan ke sebuah tujuan wisata atau destinasi wisata. Sehingga pada penelitian ini, peneliti ingin membahas Hubungan Jumlah Objek Wisata, Hotel Dan Biro Perjalanan Dengan Jumlah Kunjungan Wisatawan Ke Tujuan Wisata DIY.

\section{KAJIAN LITERATUR \\ Objek Wisata/Daya Tarik Wisata}

Ojek wisata atau sering disebut dengan daya tarik wisata (tourist attraction) adalah segala hal yang dapat menarik perhatian orang atau wisatawan untuk mengunjungi tempat tersebut. Point ini menjadi salah satu penentu utama dalam menentukan kepuasan wisatawan. Menurut UU Kepariwisataan Nomor 10 Tahun 2009 daya tarik wisata adalah segala sesuatu yang memiliki keunikan, keindahan, dan nilai yang berupa keanekaragaman kekayaan alam, budaya dan hasil buatan manusia yang menjadi sasaran atau tujuan kunjungan para wisatawan.

Ismayanti dalam (Apriliyanti dkk, 2020) memaparkan daya tarik wisata sebagai penggerak utama yang memotivasi wisatawan untuk mengunjungi suatu tempat. Indonesia khususnya memiliki banyak sekali jenisjenis tempat wisata, jenis-jenis tempat wisata berdasarkan motif wisatawan yang di rangkum dari website https://dispar.bone.go.id/ anatara lain : (1) Wisata Bahari, (2) Wisata Budaya, (3) Wisata Pertanian, (4) Wisata Buru, 
(5) Wisata Ziarah, (6) Wisata Cagar Alam, (7) Wisata Konvensi.

Hotel

Hotel merupakan salah satu akomodasi yang sangat dibutuhkan oleh wisatawan pada saat bewisata. Sujatna dalam (Derianto dan Kristiutami, 2015) menyatakan bahwa hotel merupakan sebuah perusahaan atau badan usaha akomodasi yang menyediakan pelayanan jasa penginapan, penyedia makanan, minuman, dan fasilitas kamar untuk tidur kepada orang-orang yang melakukan perjalanan dan mampu membayar dengan jumlah yang wajar sesuai dengan pelayanan yang diterima tanpa adanya perjanjian khusus. Sulastiyono dalam (Setyawan dan Wijayanti, 2014) menyatakan hotel merupakan akomodasi yang menggunakan sebagian atau seluruh bangunannya bagi semua orang untuk menyediakan pelayanan dan penginapan berikut makan dan minum. Hotel merupakan perusahaan jasa yang dikelola secara komersil.
Biro Perjalanan Wisata

Pada era saat ini banyak sekali wisatawan yang menginginkan wisatanya terorganisir sehingga mereka lebih memilih menggunakan biro perjalanan wisata atau travel agency. Damardjati dalam (Hudiyani dkk, 2018) menjelaskan bahwa Tour Agency (Biro Perjalanan) adalah sebuah perusahaan yang mengatur dan menyelenggarakan perjalanan untuk orang-orang, termasuk persinggahan dan kelengkapan perjalanan lainnya. Menurut UndangUndang No. 9 Th. 1990 disebutkan bahwa usaha jasa biro perjalanan wisata merupakan usaha penyediaan jasa perencanaan dan/atau jasa pelayanan dan penyelenggaraan wisata.

\section{Wisatawan}

Menurut Smith dalam (Wolah, 2016) menjelaskan bahwa wisatawan adalah orang yang sedang tidak bekerja, atau sedang berlibur dan secara sukarela mengunjungi daerah lain untuk mendapatkan sesuatu yang lain.

Tabel 1. Penelitian Terkait

\begin{tabular}{|c|c|c|c|}
\hline No & Nama Peneliti & Judul Penelitian & Hasil Penelitian \\
\hline 1. & Suwanto (2020) & $\begin{array}{lr}\text { Hubungan } & \text { Jumlah } \\
\text { Kunjungan Wisatawan } & \text { Dengan } \\
\text { Mancanegara } & \text { Dingkat } \\
\text { Rata-Rata } & \text { Tamar } \\
\text { Penghunian } & \text { Kam } \\
\text { Hotel Provinsi Dki } \\
\text { Jakarta Tahun 2012- } \\
2018\end{array}$ & $\begin{array}{l}\text { Analisis temuan penelitian menunjukkan } \\
\text { bahwa terdapat hubungan yang kuat, dan } \\
\text { arah hubungan yang searah (positif) } \\
\text { antara jumlah kunjungan wisatawan } \\
\text { mancanegara dengan rata-rata tingkat } \\
\text { penghunian kamar hotel Provinsi DKI } \\
\text { Jakarta. }\end{array}$ \\
\hline 2. & $\begin{array}{l}\text { Nina Sabrina dan } \\
\text { Irma Mudzhalifah } \\
(2018)\end{array}$ & $\begin{array}{lr}\text { Pengaruh Jumlah Objek } \\
\text { Wisata, Jumlah } \\
\text { Wisatawan Dan Tingkat } \\
\text { Hunian Hotel Terhadap } \\
\text { Pendapatan Asli Daerah } \\
\text { Dengan } & \text { Penerimaan } \\
\text { Sektor } & \text { Pariwisata } \\
\text { Sebagai } & \text { Variabel } \\
\text { Moderating } & \text { Pada Dinas } \\
\text { Pariwisata } & \text { Kota } \\
\text { Palembang } & \end{array}$ & $\begin{array}{l}\text { Hasil penelitian ini menunjukkan bahwa } \\
\text { Jumlah Objek Wisata, Jumlah } \\
\text { Wisatawan, dan Tingkat Hunian Hotel } \\
\text { memiliki pengaruh secara simultan yang } \\
\text { signifikan terhadap PAD, }\end{array}$ \\
\hline
\end{tabular}

Sumber : Penulis (2021)

\section{METODE PENELITIAN}

Metode dalam penelitian diproses menggunakan metode diskriptif kualitatif yang didukung pendekatan kuantitatif. Metode kualitatif digunakan untuk menterjemahkan data-data sekunder dari BAPPEDA DIY yang berupa angka menjadi lebih mudah dipahami dalam bentuk diskripsi atau pernyataan ringkas tentang kondisi objek penelitian. Pendekatan kuantitatif dengan analisis korelasi digunakan

ISSN: 2355-6587, e-ISSN: 2528-2220

http://ejournal.bsi.ac.id/ejurnal/index.php/jp 
untuk mengenali hubungan objek penelitian dengan menggunakan sample jenuh, karena keterbatasan dalam jumlah sample dan data dimasa pandemi covid19. Variabel yang digunakan dalam penelitian ini adalah $\mathrm{Y}=$ jumlah kunjungan wisatawan ke destinasi wisata di DI Yogyakarta sebagai variabel dependen; $\mathrm{X}_{1}=$ jumlah jenis objek wisata; $\mathrm{X}_{2}=$ jumlah hotel dan $\mathrm{X}_{3}$ $=$ jumlah biro perjalanan wisata sebagai variabel independen. Seluruh data bersifat sekunder yang dikumpulkan dari diterbitkan oleh Badan Perencanaa Dan Pembangunan Daerah DIY melalui website http://bappeda.jogjaprov.go.id/ mulai tahun 2009 sampai 2020. Tujuan penelitian ini adalah untuk mengetahui hubungan antara variabel dependen dengan independen. Hipotesis yang akan dibuktikan dalam penelitian ini adalah tidak terdapat hubungan parsial antara jumlah objek wisata, hotel dan biro perjalanan wisata dengan kunjungan wisatawan ke tujuan wisata di D.I. Yogyakarta.

\section{HASIL DAN PEMBAHASAN}

Melihat data hasil penelitian diketahui bahwa jenis objek wisata di Daerah Istimewa Yogyakarta terbagi dalam 7 jenis antara lain objek wisata marina, tirta, sejarah, alam, museum, desa wisata dan objek wisata lainnya. Hal ini dapat dilihat pada gambar 1 yang menunjukkan grafik jumlah dan jenis objek wisata di Yogyakarta periode tahun $2009-2020$ berikut ini.

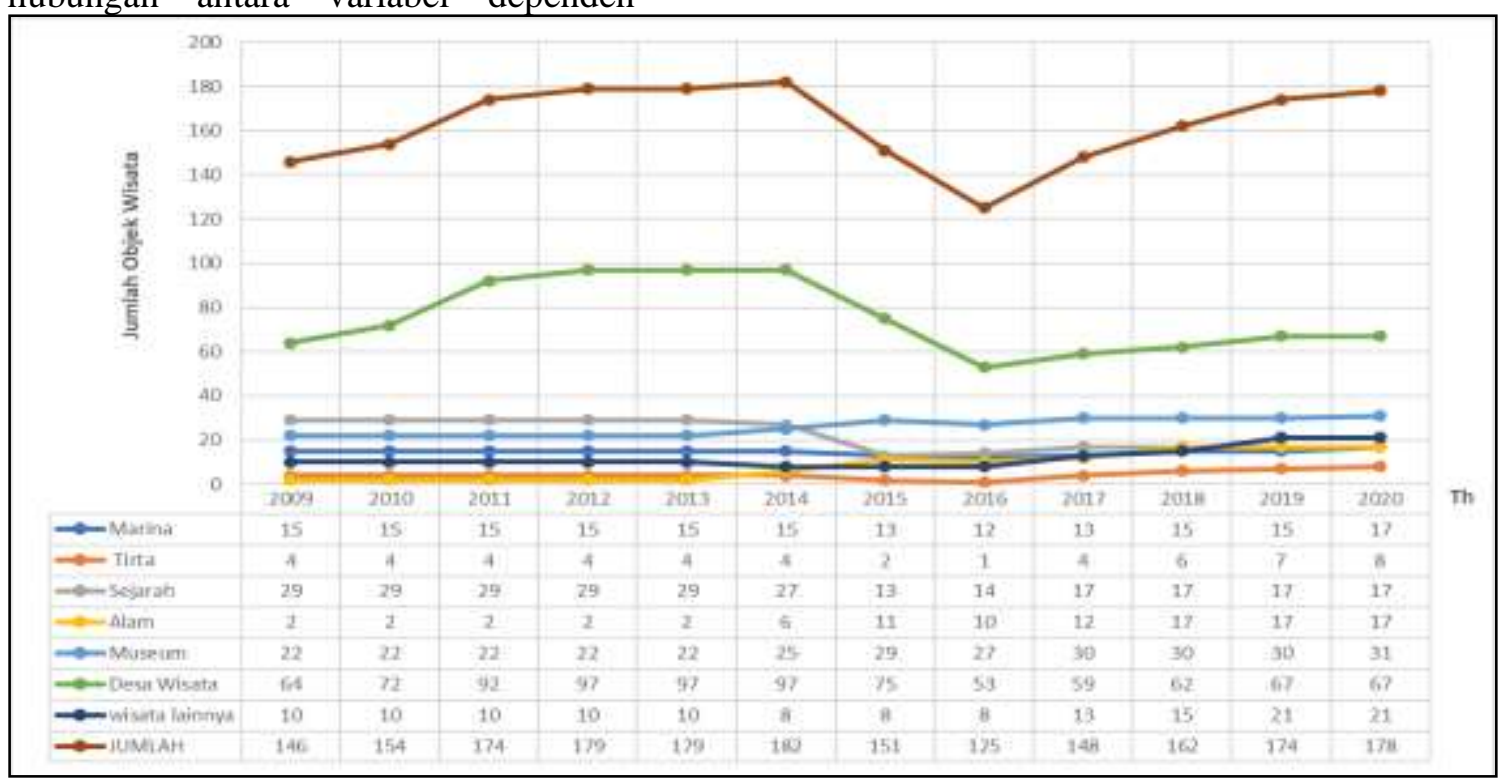

\section{Gambar 1. Data Jumlah Jenis Objek Wisata di DIY} Sumber : BAPPEDA DIY, 2021 (diolah)

Jumlah objek wisata di DIY paling tinggi ditempati jenis Desa Wisata, dimana puncak jumlah dari keseluruhan destinasi terjadi pada periode tahun 2012 - 2014 yaitu sebanyak 182 destinasi. Setelahnya diikuti penurunan drastis dari sisi jumlah maupun per jenis objek wisata sampai tahun 2016 akibat beberapa faktor diantaranya adalah bencana alam gempa bumi, letusan gunung merapi dan konsistensi pengelolaan. Namun demikian, dari ke 7 jenis objek wisata pada periode tersebut penurunan tidak terjadi atau relatif stabil pada jenis objek wisata museum dan wisata alam. Objek wisata DIY mulai bangkit kembali dan mengalami kenaikan dari sisi jumlah pada periode tahun 2017 - 2020 sebelum pandemi merebak pada awal tahun 2020 hingga mencapai jumlah 178 destinasi.

Perkembangan jumlah hotel di Daerah Istimewa Yogyakarta, secara komulatif pada periode tahun 2009 2020 mengalami peningkatan seiring dengan peningkatan jumlah wisatawan yang berkunjung ke Yogyakarta dari tahuh ke tahun, sehingga menarik 
investor membangun hotel di Yogyakarta. Perkembangan jumlah hotel per bintang di DIY periode tahun 2009 -
2020 dapat dilihat pada gambar 2 berikut ini.

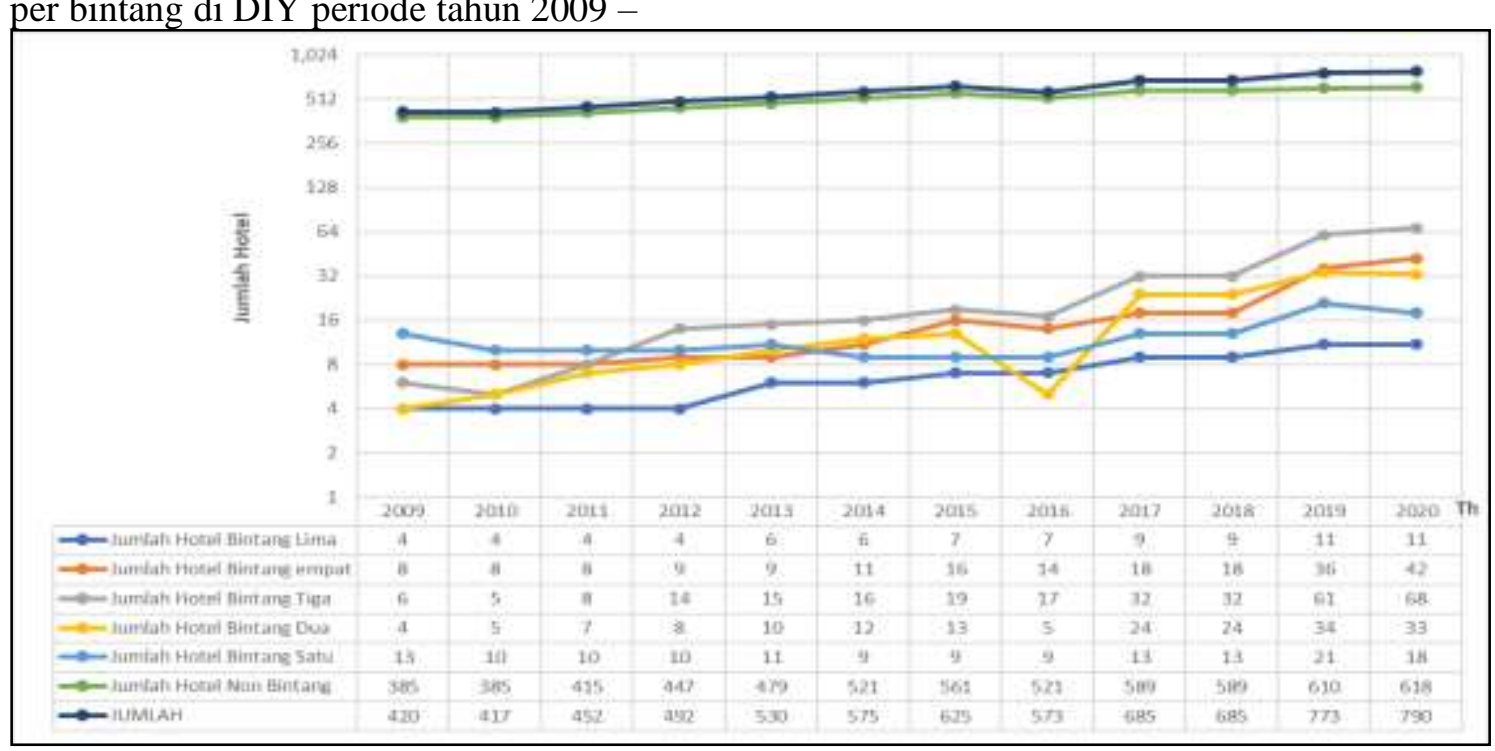

Gambar 2. Jumlah Hotel di DIY Sesuai Bintang

Sumber : BAPPEDA DIY, 2020 (diolah)

Diantara berbagai jenis hotel berbintang mulai satu sampai dengan lima dari sisi jumlah, maka hotel non bintang memiliki jumlah terbesar dan bertebaran diseluruh daerah baik kabupaten maupun kota di DIY. Penurunan jumlah dari seluruh jenis hotel terjadi pada tahun 2016 dan penurunan paling tajam ada pada jenis hotel bintang dua sebanyak 52 hotel berhenti. Sementara untuk jenis hotel bintang lima stabil tidak mengalami penurunan dari sisi jumlah pada tahun 2016. Hal ini menunjukkan bahwa hotel bintang lima cukup kuat dari sisi stakeholder walaupun diterpa berbagai macam faktor seperti bencana alam dan lainnya. Sebelum pandemi covid-19 seluruh hotel di DIY dapat bertahan sampai dengan tahun 2020. Namun demikian pada tahun 2021, saat pandemi covid-19 semakin meluas di seluruh dunia termasuk Indonesia, menurut Ketua Perhimpunan Hotel dan Restoran Indonesia (PHRI) DIY Deddy Pranowo Eryono menyatakan bahwa sebanyak 53 hotel dan restoran di Yogyakarta memilih tutup permanen dengan alasan tidak dapat menutup biaya operasional per bulan (Pangaribowo, 2021). Hal ini akibat dari jumah kunjungan wisatawan yang terbatas dibanding sebelum pandemi. Dari 53 hotel tersebut 32 merupakan hotel dan sisanya usaha restoran.

Perkembangan jumlah biro perjalanan wisata sebagai bagian dari industri pariwisata yang memiliki kepentingan terhadap ketersediaan paket wisata beserta armada perjalanannya keseluruh daerah tujuan wisata. Sejak tahun 2009 sampai dengan tahun 2020 secara grafik data menunjukkan adanya perkembangan yang signifikan dari tahun ke tahun. Hampir setiap tahun mengalami kenaikan dari sisi jumlah. Mereka memilik peran penting dalam penyelenggaraan ataupun pengorganisasian perjalanan wisata dengan berbagai paket wisata yang disediakan beserta fasilitas pendukung kegiatan wisatanya. Penurunan jumlah biro perjalanan wisata hanya terjadi pada tahun 2016, dimana pada tahun tersebut terjadi bencana alam gempa bumi yang berpusat di Kabupaten Bantul. Kondisi ini cukup berpengaruh sehingga ditahun 2016 terjadi penurunan jumlah penyedia perjalanan sebanyak 82 biro perjalanan wisata berhenti atau tutup. 


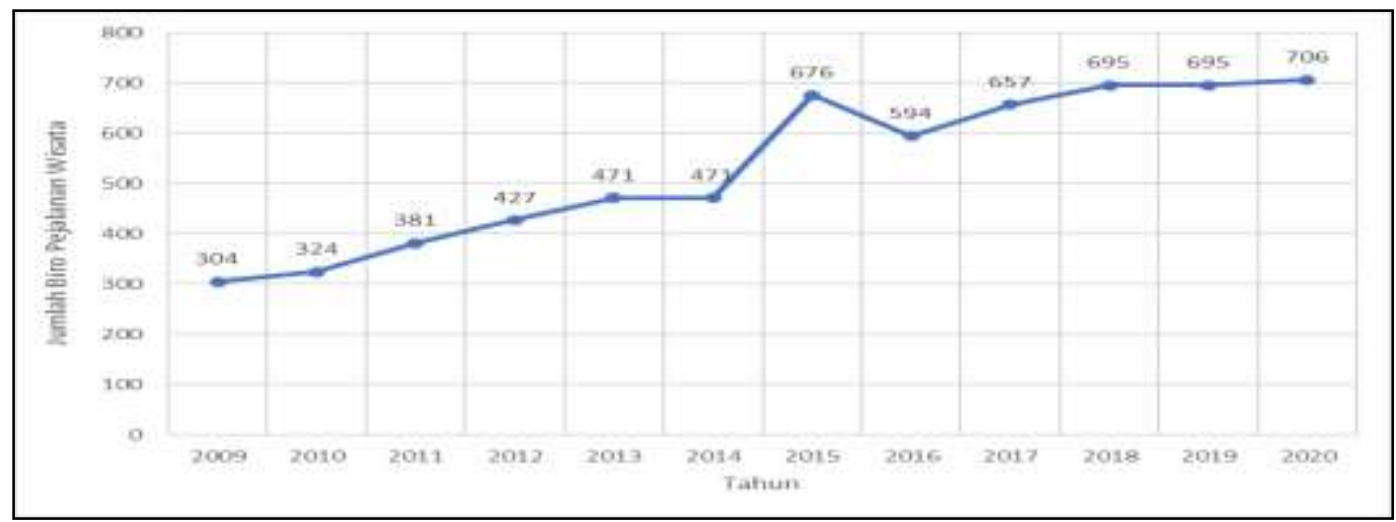

Gambar 3. Jumlah Biro Perjalanan Wisata di DIY

Sumber : BAPPEDA DIY, 2020 (diolah)

Peningkatan jumlah biro perjalanan wisata dari tahun ke tahun mengindikasikan banyaknya potensi wisatawan yang menggunakan jasa industri ini untuk mengatur perjalanan wisatanya. Wisatawan tidak dipusingkan dengan daerah wisata mana yang akan dituju, karena telah dimudahkan biro perjalanan dengan adanya pilihan paket wisata meliputi beberapa daerah tujuan dan dapat disesuaikan dengan budged anggaran calon wisatawan.

Sementara perkembangan jumlah kunjungan wisatawan nusantara (WISNUS) ke destiansi wisata di Yogyakarta dengan data grafik sejak tahun 2012 mengalami peningkatan yang baik sampai dengan akhir tahun 2019. Penurunan jumlah kunjungan terjadi mulai awal tahun 2020 akibat adanya pandemik covid-19 yang semakin meluas diseluruh kota di Indonesia. Jenis objek wisata marina masih menjadi idola wisatawan nusantara dibanding yang lain. Penurunan jumlah objek wisata hanya terjadi pada jenis desa wisata sejak tahun 2016 sampai dengan 2018. Hal ini terjadi dikarenakan adanya bencana alam dimana sebagian dari lokasi desa wisata berada di kabupaten Bantul yang dilanda bencana gempa bumi ditahun 2016, sehingga mempengaruhi aktivitas pengelolaan desa wisata yang ada.

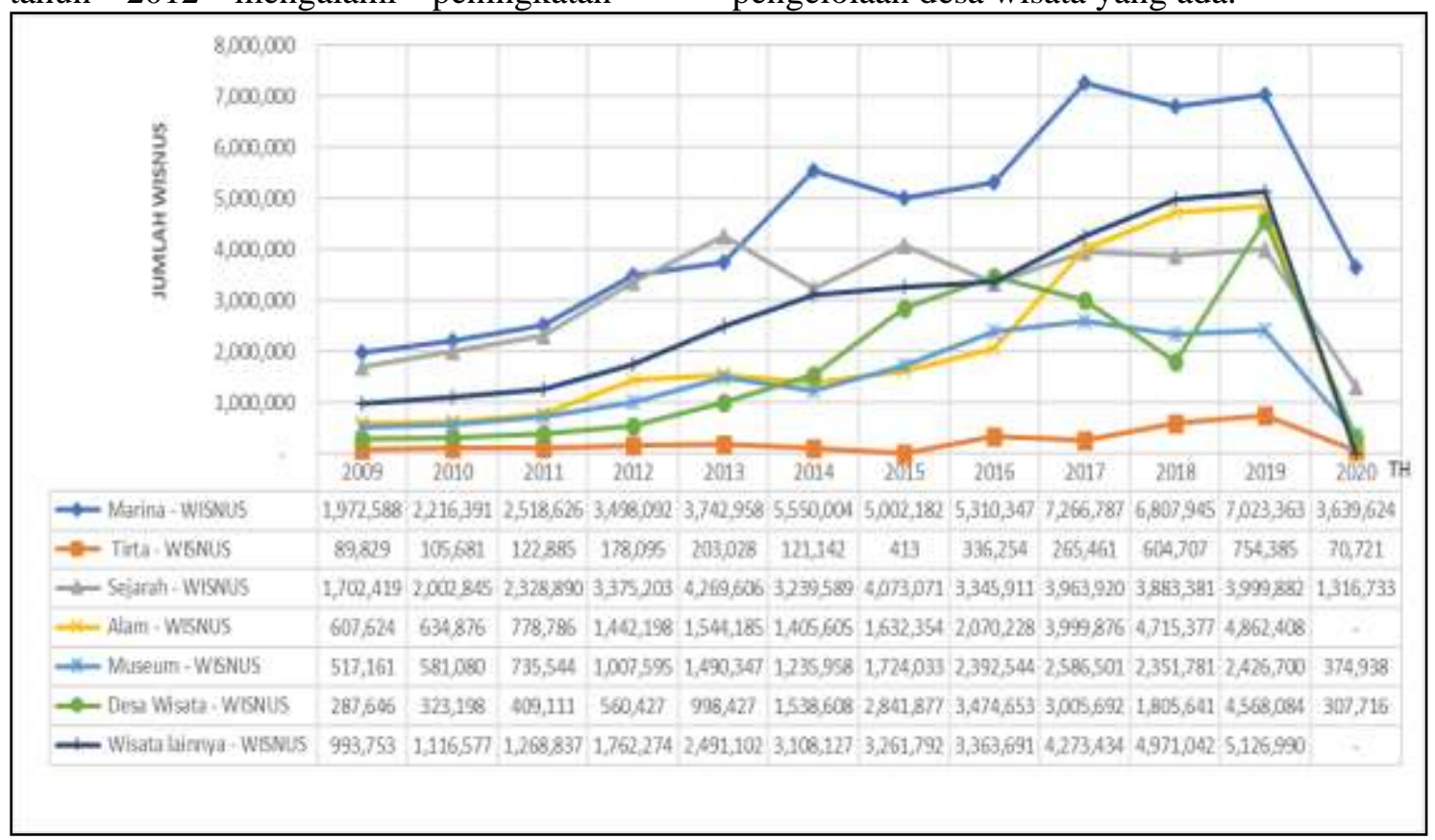

Gambar 4. Jumlah Kunjungan Wisatawan Nusantara Ke Objek Wisata Di DIY Sumber : BAPPEDA DIY, 2020 (diolah)

ISSN: 2355-6587, e-ISSN: 2528-2220

http://ejournal.bsi.ac.id/ejurnal/index.php/jp 
Dilihat dari grafik menunjukkan bahwa potensi besar untuk wisatawan nusantara adalah jenis destinasi marina seperti pantai, alam dan wisata lainnya. Sedengakan objek wisata yang masih membutuhkan untuk bergerak menambah jumlah wisatawan adalah jenis wisata tirta.

Dikategori wisatawan manca negara (WISMAN) dari sisi jumlah kunjungannya mengalami fluktuasi dari tahun ke tahun sesuai dengan kondisi global yang terjadi. Penurunan jumlah wisatawan mancanegara secara drastis turn di akhir tahun 2020 untuk semua jenis destinasi, terkecuali jenis objek wisata museum. Keadaan ini dapat dilihat pada gambar grafik jumlah wisatawan manca negara yang berkunjung disejumlah objek wisata yang berada di Yogyakarta berikut ini.

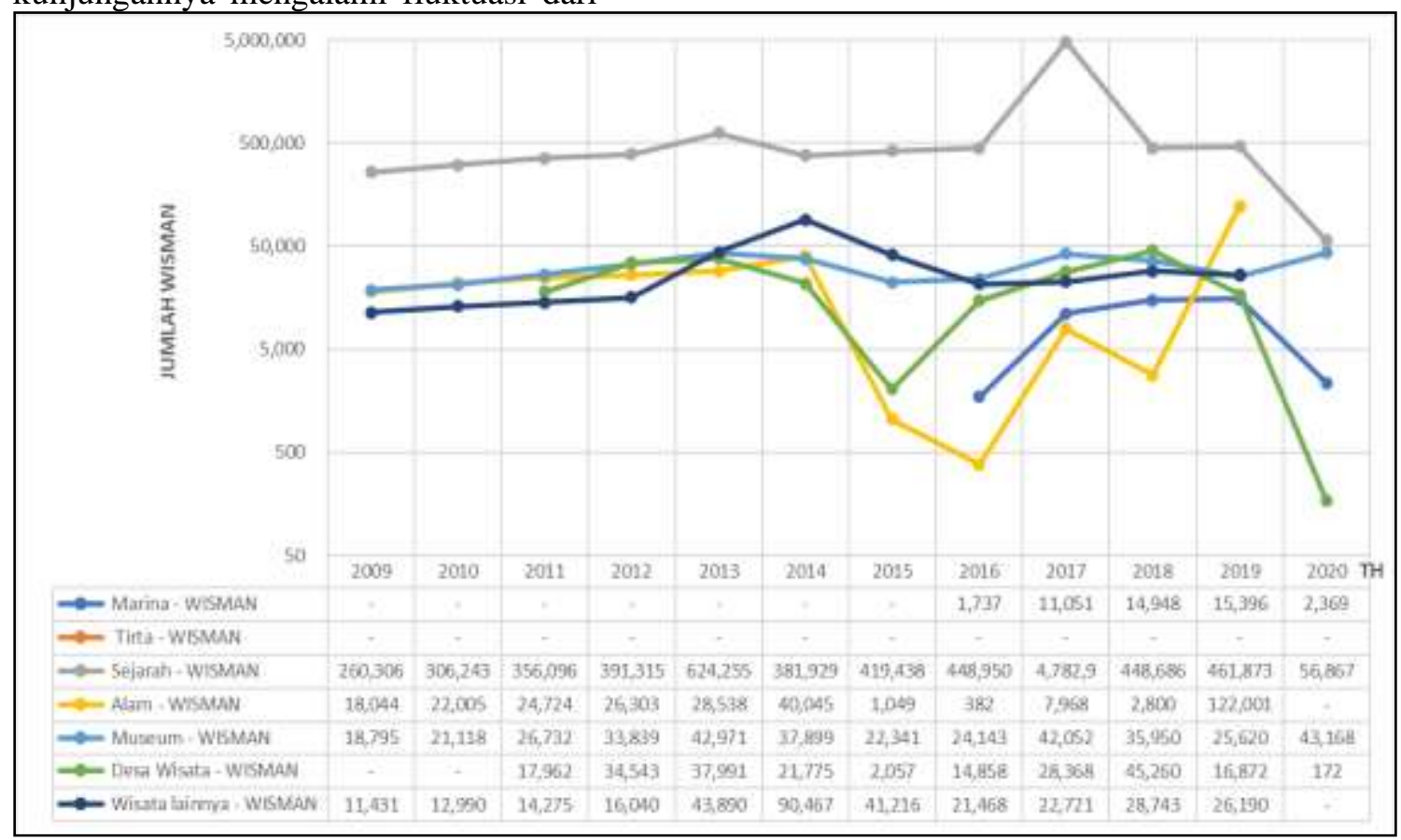

Gambar 5. Jumlah Kunjungan Wisatawan Manca Negara Ke Objek Wisata Di DIY Sumber : BAPPEDA DIY, 2020 (diolah)

Dari keempat variable penelitian sebelumnya maka dapat dijelaskan bahwa sejak tahun 2009 sampai dengan tahun 2020, mulai dari jumlah jenis objek wisata, jumlah hotel dan biro perjalanan secara umum mengalami kenaikan dari sisi jumlah. Dan secara bersama-sama mengalami sedikit penurunan pada tahun 2016 sebagai dampak terjadinya bencana alam di Yogyakarta. Sedangkan jumlah wisatawan sebagai variabel independen secara umum juga mengalami hal yang sama sejak tahun 2009 sampai tahun 2019 mengalami peningkatan seiring dengan peningkatan variable independen, terkecuali pada akhir tahun 2020 yang menurun sebagai dampak dari bencana dalam bentuk pandemi covid-19.

Berdasarkan temuan keadaan diatas, dalam penelitian perlu dibuktikan dengan korelasi sederhana untuk menguji hubungan variabel independen yaitu jumlah objek wisata, hotel dan biro perjalanan dengan jumlah wisatawan sebagai variabel dependen. Analisis korelasi ini digunakan untuk mengetahui hubungan antara variabel bebas (independen) terhadap variabel terikat (dependen). Hasil olah data statistik dengan menggunakan SPSS menghasilkan tabel karelasi yang digunakan untuk mengetahui bentuk hubungan antara variabel bebas dan terikat dengan hasil pada tabel sebagai berikut : 
Tabel 2. Correlations

\begin{tabular}{|c|c|c|c|c|c|}
\hline Varible & $\begin{array}{c}\text { Correlation } \\
\text { Type }\end{array}$ & $\begin{array}{c}\text { Jumlah } \\
\text { Objek } \\
\text { Wisata }\end{array}$ & $\begin{array}{l}\text { Jumlah } \\
\text { Hotel }\end{array}$ & $\begin{array}{c}\text { Biro } \\
\text { Perjalanan } \\
\text { Wisata }\end{array}$ & $\begin{array}{c}\text { Jumlah } \\
\text { Wisatawan }\end{array}$ \\
\hline \multirow{4}{*}{$\begin{array}{l}\text { Jumlah } \\
\text { Objek } \\
\text { Wisata }\end{array}$} & Pearson & 1 & .150 & -.048 & -.196 \\
\hline & Correlation & & & & \\
\hline & Sig. (2-tailed) & & .642 & .883 & .541 \\
\hline & $\mathrm{N}$ & 12 & 12 & 12 & 12 \\
\hline \multirow{4}{*}{$\begin{array}{l}\text { Jumlah } \\
\text { Hotel }\end{array}$} & Pearson & .150 & 1 & $.944^{* * *}$ & $.583^{*}$ \\
\hline & Correlation & & & & \\
\hline & Sig. (2-tailed) & .642 & & .000 & .047 \\
\hline & $\mathrm{N}$ & 12 & 12 & 12 & 12 \\
\hline \multirow{4}{*}{$\begin{array}{l}\text { Biro } \\
\text { Perjalanan } \\
\text { Wisata }\end{array}$} & Pearson & -.048 & $.944^{* *}$ & 1 & $.672^{*}$ \\
\hline & Correlation & & & & \\
\hline & Sig. (2-tailed) & .883 & .000 & & .017 \\
\hline & $\mathrm{N}$ & 12 & 12 & 12 & 12 \\
\hline \multirow{4}{*}{$\begin{array}{l}\text { Jumlah } \\
\text { Wisatawan }\end{array}$} & Pearson & -.196 & $.583^{*}$ & $.672^{*}$ & 1 \\
\hline & Correlation & & & & \\
\hline & Sig. (2-tailed) & .541 & .047 & .017 & \\
\hline & $\mathrm{N}$ & 12 & 12 & 12 & 12 \\
\hline \multicolumn{6}{|c|}{ **. Correlation is significant at the 0.01 level (2-tailed). } \\
\hline \multicolumn{6}{|c|}{ *. Correlation is significant at the 0.05 level (2-tailed). } \\
\hline
\end{tabular}

Dari output table korelasi diatas dapat diketahui bahwa terdapat hubungan antara jumlah hotel dengan jumlah kunjungan wisatawan sebesar $0,583 *$. Sifat korelasi menunjukkan positf, artinya semakin tinggi jumlah hotel akan semakin tinggi jumlah kunjungan wisatawan. Nilai signifikansi sebesar 0,047 berarti hubungan tersebut cukup signifikan atau diterima pada probablitias 5\%. Demikian pula untuk jumlah biro perjalanan wisata yang menunjukkan adanya hubungan dengan jumlah wisatawan sebesar $0,672 *$. Korelasi ini menunjukkan nilai positif, sehingga semakin tinggi jumlah biro perjalanan wisata semakin besar pula jumlah kunjungan wisatawan. Nilai signifikansi adalah 0,017, artinya terdapat hubungan yang signifikan pada probabilitas $5 \%$. Sedangkan varibel jumlah objek wisata tidak memiliki hubungan yang erat terhadap jumlah kunjungan wisatawan sebagaimana terlihat pada tabel 2 dimana nilai korelasinya adalah sebesar $-0,196$ dengan tingkat signifikasi 0,541 lebih besar dari nilai signifikansi 0,000. Jika diamati dari sebaran data pada grafik gambar 4 dan 5, maka jenis objek wisatalah yang memiliki potensi hubungan yang erat dengan jumlah kunjungan wisatawan dibandingkan jumlah objek wisatanya sendiri.

\section{PENUTUP}

Penelitian ini menghasilkan kesimpulan bahwa sejak tahun 2009 sampai dengan 2020, secara umum telah terjadi peningkatan jumlah baik dari variabel independen untuk jumlah objek wisata, hotel dan biro perjalanan wisata serta variabel independen untuk jumlah kunjungan wisatawan ke Daerah Istimewa Yogyakarta. Hipotesis pada penelitian ini tidak terbukti karena terdapat hubungan parsial antara jumlah hotel dan biro perjalanan wisata terhadap jumlah kunjungan wisatawan dengan nilai signifikansi mendekati 0,000 pada tingkat probabilitas $5 \%$. Sedangkan jumlah destinasi wisata tidak memiliki hubungan yang erat dengan jumlah kunjungan wisatawan. Hal ini

ISSN: 2355-6587, e-ISSN: 2528-2220

http://ejournal.bsi.ac.id/ejurnal/index.php/jp 
berdasarkan variasi sebaran jumlah data pada grafik 4 dan 5 yang menunjukkan potensi hubungan ada pada jenis objek wisata dan bukan dari jumlahnya. Artinya tidak semua orang yang melakukan perjalanan dengan biro dan menginap di hotel terpengaruh oleh jumlah objek wisata, namun faktor jenis objek wisatalah yang akan menjadi pertimbangan tamu untuk berkunjungan ke suatu objek wisata di D.I. Yogyakarta.

Pada artikel penelitian ini masih terdapat banyak kekurangan khususnya informasi berupa data-data sekunder yang lengkap dari tahun-ketahun, sehingga penulis tidak dapat melakukan proses analisis lebih jauh. Oleh karena itu sebagai acuan bagi peneliti lain yang akan melakukan penelitian lebih lanjut. Analisis regresi linier diperlukan untuk mengetahui seberapa besar pengaruh dari ketiga variable independen tersebut terhadap variabel dependennya.

\section{REFERENSI}

Anonim. Undang Undang tentang Kepariwisataan, UU No. 9 Tahun 1990. Jakarta: Menteri Sekretaris Negara

Anonim. Undang Undang tentang Kepariwisataan, UU No. 10 Tahun 2009. Jakarta: Direktorat Jenderal Hukum dan HAM

Anonim. Jenis-Jenis Tempat Wisata Berdasarkan Motif Wisatawan, Lokasi Tujuan, dan Perjalanan. Retrieved September, 30, 2021, from

https://dispar.bone.go.id/2019/02/j

enis-jenis-tempat-wisata-

berdasarkan-motif-wisatawanlokasi-tujuan-dan-perjalanan/

Anonim. Pariwisata. Retrieved September, 30, 2021 from http://bappeda.jogjaprov.go.id/dat aku/data_dasar/index/

Apriliyanti, Ester ;Syarifah Hudayah dan Saida Zainurossalamia. 2020. Pengaruh Daya Tarik Wisata, Citra Destinasi Dan Sarana Wisata Terhadap Kepuasan Wisatawan Citra Niaga Sebagai
Pusat Cerminan Budaya Khas

Kota Samarinda. Jurnal

Manajemen. Vol 12 No 1. Hlm

145-153 Diambil dari

https://journal.feb.unmul.ac.id/ind

ex.php/JURNALMANAJEMEN/a rticle/view/7308/pdf

Derianto, Panji Septian dan Yuliana Pinaringsih Kristiutami. 2015. Standar Operasional Prosedur Room Service Amaroosa Hotel Bandung. Vol.II No.1 Hlm 15-21 Di ambil dari https://ejournal.bsi.ac.id/ejurnal/in dex.php/jp/article/download/295/2 82

Fathiyah. 5 Alasan Kenapa Yogyakarta menjadi Destinasi Favorit. Retrieved September, 30, 2021, from https://yoursay.suara.com/ulasan/ 2021/06/23/194455/5-alasankenapa-yogyakarta-menjadidestinasi-favorit

Hudiyani, Anisa; Aspan ; dan Nur Fitri Yana. 2018. Peran Tour Agency Orangutan Journey Dalam Peningkatan Kunjungan Wisatawan Di Taman Nasional Tanjung Puting Kabupaten Kotawaringin Barat. Jurnal Magenta. Vol 7 No 1. Hlm 35-42. Di ambil dari http://magenta.untama.ac.id/index .php/1192012/article/viewFile/31/ 30

Pangaribowo, Wisang Seto. 2021. "53 Hotel dan Restoran di DIY Pilih Tutup Permanen karena Covid19", Editor : Ni Nyoman Wira Widyanti, Retrieved September, 30, 2021, from https://travel.kompas.com/read/20 21/05/22/153800327/53-hoteldan-restoran-di-diy-pilih-tutuppermanen-karena-covid-19.

Sabrina, Nina dan Irma Mudzhalifah. 2018. Pengaruh Jumlah Objek Wisata, Jumlah Wisatawan Dan Tingkat Hunian Hotel Terhadap Pendapatan Asli Daerah Dengan Penerimaan Sektor Pariwisata Sebagai Variabel Moderating 
Pada Dinas Pariwisata Kota Palembang . Jurnal Akutansi dan Bisnis. Vol 3 No 2. Hlm 464-473. Di ambil dari https://jurnal.umpalembang.ac.id/balance/article/vi ew/1449/1231

Setyawan, Heri Dan Ani Wijayanti. 2014. Standar Operasional Reservation Section Di Cakra Kusuma Hotel Yogyakarta. Khasanah Ilmu- Jurnal Pariwisata Dan Budaya. Vol.5, No.2, 25-33. Di ambil dari https://ejournal.bsi.ac.id/ejurnal/in dex.php/khasanah/article/view/50 5

Suwanto. 2020. Hubungan Jumlah Kunjungan Wisatawan Mancanegara Dengan Rata-Rata Tingkat Penghunian Kamar Hotel Provinsi Dki Jakarta Tahun 2012-2018. Jurnal Kepariwisataan Indonesia. Vol 14 No 1. Hlm 9-20 Di ambil dari http://ejournal.kemenparekraf.go.i d/index.php/jki/article/view/150/3 9

Wolah, Ferni Fera Ch. 2016. Peranan Promosi Dalam Meningkatkan Kunjungan Wisatawan Di Kabupaten Poso. Jurnal Acta Diurna. Vol 5 no 2. Hlm Di ambil dari

https://ejournal.unsrat.ac.id/index. php/actadiurnakomunikasi/article/ view/11722

\section{BIODATA PENULIS}

Atun Yulianto, adalah dosen Universitas BSI Fakultas Ekonomi dan Bisnis Program Studi Perhotelan. Saat ini aktif dalam berbagai penelitian terkait kepariwisataan dan menjadi reviewer pada beberapa jurnal nasional.

Citra Unik Mayasari, merupakan salah satu dosen tetap Universitas BSI Fakultas Ekonomi dan Bisnis Program Studi Perhotelan. Saat ini aktif dalam berbagai penelitian terkait kepariwisataan, kuliner dan perhotelan. 